\title{
A STUDY ON HOSPITAL WASTE MANAGEMENT OF SYLHET CITY IN BANGLADESH
}

\author{
Shilpy Rani Basak, Ayesha Ferdous Mita, Nusrat Jahan Ekra, Md. Jahir Bin Alam \\ Department of Civil and Environmental Engineering \\ Shahjalal University of Science and Technology, Sylhet, Bangladesh
}

\begin{abstract}
Infectious and hazardous medical waste poses a deliberate threat to environmental health and needs special treatment and management prior to its ultimate disposal. Many of hospitals in Sylhet have neither a satisfactory waste management system nor a disposal policy. This study represents the present status of Hospital Waste (HW) management in Sylhet city, Bangladesh. A survey has been conducted using a questionnaire to collect information about the practices related to waste segregation, collection procedures, the type of temporary storage containers, on-site transport and central storage area, treatment of wastes, off-site transport, and final disposal options. Physico-chemical characteristics of medical wastes also have been determined according to standard methods. In developing nations like Bangladesh contrasted with developed countries, the management of infectious wastes has not received adequate consideration. The generation rate of medical waste is the key data for assessing and planning the transfer arrangement of medical waste. The waste generation rate of every unit in a hospital is diverse. The waste of every unit requires an alternate sort of analysis and treatment. It has been found that waste generation rates in government hospitals are higher than in private hospitals. Effective medical waste management programs are multispectral and require cooperation between all levels of implementation, from national and local governments to hospital staff and private organizations.
\end{abstract}

Keywords- Medical Waste, Waste Generation, Segregation, Waste Management.

\section{INTRODUCTION}

A hospital is a service-oriented residential establishment that provides medical care facilities containing observational, indicative, remedial and rehabilitative administrations for people experiencing or suspected to experience the ill effects of any sort of infection or damage. It is a complex multidisciplinary framework, where patients' issues are analyzed, dissected and treated. During these exercises, production of strong waste is unavoidable.

The World Health Organization (WHO)(2000) defines hospital solid waste as "any solid waste that is generated in the diagnosis, treatment, or immunization of human beings or animals, in research pertaining thereto, or testing of biological, including but not limited to: soiled or blood-soaked bandages, culture dishes and other glassware ". Alagöz and Kocasoy (2008) also include discarded surgical gloves and instruments, needles, lancets, cultures, stocks and swabs used to inoculate cultures and removed body organs. Prüss-Üstün, et. al. (1999a) explained that exposure to risky health care waste can bring about illness or damage. Mato and Kassenga (1997) mentioned that diseases like typhoid, cholera, AIDS, and viral hepatitis B can be transmitted through the mishandling of hazardous hospital waste. Nemathaga, et. al. (2008) explained that environmental nuisance may also emerge because of foul odor, flies, cockroaches, rodents, and vermin in addition to pollution of underground water tables by untreated medical waste in landfills. Thus, hospital waste is required to be treated in an exceptional manner and not to be blended with municipal waste. Proper medical waste management requires special treatment of medical waste, for example, incineration or hazardous waste landfill facilities. Li and Jenq (1993) have demonstrated that the best available technology for discarding medical waste is incineration. The best possible gathering of medical waste will diminish the volume of infectious wastes and consequently the expense of treatment. A better understanding of the composition of hospital waste is essential in order to choose the best disposition alternative.

According to Tudor, et. al. (2005) hospital wastes have received inadequate consideration in developing nations. In numerous countries, Da Silva, et. al. (2005) mentioned in their paper that hazardous and medical wastes are still handled and discarded together with household wastes, exposing civic employees, people in general, and the environment to major health risks. In other developing nations, waste disposal options are restricted and little scale incinerators have been utilized as an interval arrangement. Whereas in developed nations, regulation and good practice guidelines characterize 


\section{International Journal of Engineering Applied Sciences and Technology, 2019 \\ Vol. 4, Issue 5, ISSN No. 2455-2143, Pages 36-40 \\ Published Online September 2019 in IJEAST (http://www.ijeast.com)}

hospital wastes and express the different potential ways for gathering, transport, loading and transfer of such wastes. Moreover, according to Tudor, et. al. (2005) the best accessible technologies are utilized for the improvement of alternatives for appropriate disposal of medical wastes with negligible threats to human wellbeing and the environment.

This study was carried out to discover the existing scenario of hospital waste management system of Sylhet city in Bangladesh and to provide some recommendations to improve the present status of medical waste management of Sylhet city.

\section{Methodology}

The study was carried out in Sylhet region. In this study preliminary survey, questionnaire survey, physical observation and survey for finding waste generation rates were conducted. No statistically rigorous sampling procedure could be followed for this study. The methodology for this study included empirical field observation and field level data collection using both formal and informal interviews. The questionnaire mainly addressed the issues of: (a) types of generated medical wastes; (b) sources of medical wastes; (c) amount of generated wastes; and (d) existing waste management practices. The collected data and information were analyzed to assess existing waste management system, its limitation and impacts. An integrated management plan was recommended for efficient disposal of hospital waste. Site visits were conducted at all selected government, private and non-governmental hospitals to gather basic information and assess working conditions in addition to other administrative arrangements. In this study, the classification criteria were based on potential risks and divided into two categories: hazardous and non-hazardous waste. Waste from the hospitals was separated into its different components by the survey team. The quantities ( $\mathrm{kg} /$ day) and rate of waste generation (kg/bed/day) of medical and general solid waste were recorded outside the hospital building. Solid waste of both types (general and medical) was weighed individually with the help of the staff, and the weight was recorded by the field workers. The different categories of waste were weighed separately and results were recorded. Finally, data forms were completed and stored for further analysis.

\section{RESULTS AND DISCUSSIONS}

This exploratory study attempted to explain the situation of healthcare waste management in twelve selected hospitals in Sylhet region, with a focus on handling practices, occupational safety, and the implementation status of waste management policy together with other appropriate strategy issues. The components, composition, and quantities must be assessed and confirmed to form the basis of planning, design, and implementation of waste management facilities.

\section{A. Observation of the Survey Work}

The generation and management of hospital waste were discovered by the survey work. It was found that most of the wastes were thrown into open places and different types of hospital waste were noticed at a single time. As a result, wastes were found as a scattered condition, which was made by dog, cats, and scavenging birds. There was no proper method for estimating the total quantity of wastes on those hospitals and clinics.

When Sylhet City Corporation (SCC) was visited, the authority was unable to give any document about the quantity of HW. According to the assumption of SCC authority, approximate quantity of $\mathrm{HW}$ is 5-6 tones/day (compacted waste). Wastes are collected 2-3 times in a week. There is no system for collecting the wastes that are generated daily from these hospitals and clinics. There are two pick up (capacity 3 ton) and one compaction vehicle (5-6 ton) for collecting waste. There are 3-4 laborers for each vehicle. These collected wastes are then moved to the dumping sites, which is located in Lalmatia, Sylhet.

In addition, the dumping site was visited. Unfortunately, workers do not separate these wastes according to the types. They dump all the wastes together in one place.

\section{B. Result of questionnaire survey:}

Questionnaire was filled with questions about different aspects of hospital waste management. The wastes were collected, weighted, and recorded for checking data given by hospitals. Kuchibanda and Mayo (2015) estimated number of sampling for assessment of health risk created from poor management of hospitals in a municipality based on $5 \%$ error. In this study, we followed the same sampling procedure.

Table-1. List of the hospital surveyed

\begin{tabular}{|c|c|c|}
\hline $\begin{array}{c}\text { Hospitals /clinics } \\
\text { No } \\
\text { of } \\
\text { bed }\end{array}$ & Type \\
\hline $\begin{array}{c}\text { Sylhet Osmani Medical College } \\
\text { Hospital }\end{array}$ & 1080 & Government \\
\hline $\begin{array}{c}\text { Sylhet Shahid Shamsuddin } \\
\text { Hospital }\end{array}$ & 90 & Government \\
\hline T.B Hospital & 56 & Government \\
\hline $\begin{array}{c}\text { Jalalabad Ragib Rabeya Medical } \\
\text { College Hospital }\end{array}$ & 700 & Private \\
\hline $\begin{array}{c}\text { North East Medical College } \\
\text { Hospital }\end{array}$ & 500 & Private \\
\hline General Shisu Hospital & 75 & Private \\
\hline Noorjahan Hospital & 130 & Private \\
\hline Niramoy Poly Clinic & 39 & Private \\
\hline City Poly Clinic & 30 & Private \\
\hline Gazi Borhanuddin Hospital LTD & 27 & Private \\
\hline Ayesha Medicare & 25 & Private \\
\hline Central Hospital & 25 & Private \\
\hline
\end{tabular}

Table-2. Number of interviewers conducted for hospital staff

\begin{tabular}{|c|c|c|c|}
\hline Interviewers & $\begin{array}{c}\text { Government } \\
\text { Hospital }\end{array}$ & $\begin{array}{c}\text { Private } \\
\text { Hospital }\end{array}$ & Total \\
\hline In charge & 1 & 2 & 3 \\
\hline
\end{tabular}




\begin{tabular}{|c|c|c|c|}
\hline Nurse & 2 & 2 & 4 \\
\hline $\begin{array}{c}\text { Administrative } \\
\text { officer }\end{array}$ & 2 & 2 & 4 \\
\hline Doctor & 2 & 2 & 4 \\
\hline Student & 2 & 1 & 3 \\
\hline Word boy & 1 & 1 & 2 \\
\hline
\end{tabular}

\section{Waste generation}

Waste generation depends on the hospital's capacity, the number of medical staff, and the connected practices. Consequently, an on-site assessment of the hospital waste generated is considered the most proper strategy.

In this study, non-hazardous waste was categorized into general and reusable waste whereas hazardous waste was categorized into clinical and sharp waste.

It is observed that the average rate of waste generation of government hospitals $(1.22 \mathrm{~kg} / \mathrm{bed} / \mathrm{day})$ is much higher than private hospitals $(0.705 \mathrm{~kg} / \mathrm{bed} / \mathrm{day})$. Another important thing is in hospitals $0.957 \mathrm{~kg} / \mathrm{bed} /$ day waste was non-hazardous and $0.229 \mathrm{~kg} / \mathrm{bed} /$ day was hazardous waste on an average.

\section{Quantity of waste produced}

There are no actual measurement and analysis to calculate the waste generation rate of government and private hospitals. The procedure presented by Hossain (2014) is followed in this study:

Waste generation rate $=$ Average waste production/patient/day $\times$ Total no. of patients visited/ day $\times$ Total no. ofhospitals.

Total generated waste in government hospitals $=(1.22 \times$ $750 \times 3) \mathrm{kg}=2745 \mathrm{~kg}$, considering 750 patients treated per day. Total generated waste in private hospitals $=(0.705 \times 1000 \times 9)$ $\mathrm{kg}=634.5 \mathrm{~kg}$, considering 100 patients treated per day.

\section{E. Hospital waste composition}

Circumstantial waste characterization is of no great significance because of the waste stream's heterogeneity. The focus of concern is on infectious wastes and on their proper treatment and disposal. Waste generated in various activities carried out in the hospitals can be classified into following categories:

Table-3. Different Waste types

\begin{tabular}{|l|l|l|}
\hline Pathological & Food proportions & $\begin{array}{l}\text { Surgery wastes } \\
\text { Blood }\end{array}$ \\
Other fluids & Dialysis & $\begin{array}{l}\text { Discarded lines } \\
\text { categories etc. } \\
\text { Sharps }\end{array}$ \\
\hline
\end{tabular}

Fig.1: Hazardous medical Waste

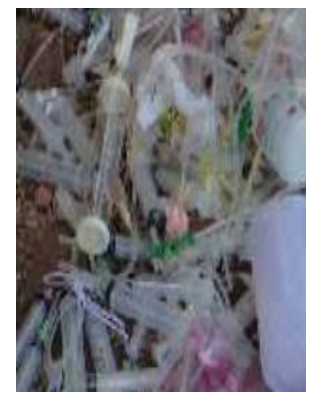

Fig.2: Exposure of workers in Local medical college

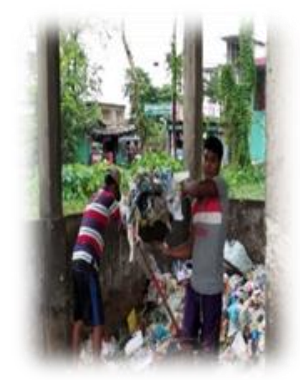

Fig.3: Scattered Medical Waste

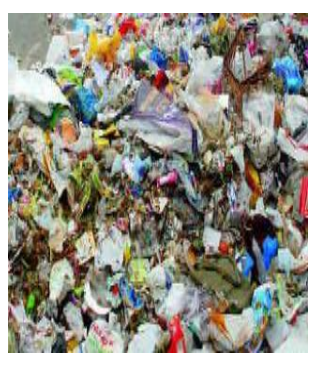

This waste composition of hospital is different for various hospitals. It is clear from survey work that the waste contains halogen hydrocarbon (17\%), radioactive (23\%), others $(60 \%)$.

\section{F. Use of care product}

Questionnaire was filled with the questions about what type of care product the laborer uses during work.

Table-4. Use of care product by laborer

\begin{tabular}{|l|l|l|}
\hline Care product & Yes & No \\
\hline Helmets & $20 \%$ & $80 \%$ \\
\hline Face masks & $35 \%$ & $75 \%$ \\
\hline Eye protector & $0 \%$ & $100 \%$ \\
\hline Apron protector & $0 \%$ & $100 \%$ \\
\hline $\begin{array}{l}\text { Leg } \\
\text { (boots) }\end{array}$ & $67 \%$ & $23 \%$ \\
\hline Gloves & $45 \%$ & $55 \%$ \\
\hline
\end{tabular}

G. Health risk due to poor waste management in hospitals It is clear from the focus group discussion with doctors and staffs that the following health hazards generally occurred due to poor handling of hospital wastes in surveyed hospitals:

- Improper practices such as dumping of bio-medical waste in municipal dustbins, open spaces, water bodies' etc. resulting in the spread of diseases

- Exposure to radioactive waste in the waste stream causing serious health hazards

- Risks of infections outside hospital for waste handlers, scavengers and (eventually) the general public

- $\quad$ Severe pain due to sharp- inflicted injuries for many years through handling sharp wastes with bare hands

- Toxic exposure to pharmaceutical products in particular, antibiotics and cytotoxic drugs

- Air pollution arising because of the release of particulate matter during medical waste incineration

- Thermal injuries occurring in conjunction with open burning and the operation of medical waste incinerators 


\section{International Journal of Engineering Applied Sciences and Technology, 2019 \\ Vol. 4, Issue 5, ISSN No. 2455-2143, Pages 36-40 \\ Published Online September 2019 in IJEAST (http://www.ijeast.com)}

- Viral diseases like cholera, dysentery and typhoid fever

- Different types of skin diseases.

It is clear from survey and observation that worker and people are in risk in Sylhet due to poor handling of hospital waste. Health risk from improper hospital waste management is a matter of concern. It is time to take proper action and planning to handle hospital waste in Sylhet.

\section{H. Shortcoming in existing system}

The segregation of waste in almost all hospitals is not satisfactory. The shortcoming of existing hospital waste management system which has been found through focus group discussion are as follows:

- Color coding for various categorized waste is not followed.

- The storage of bio medical waste is not in isolated area and proper hygiene is not maintained.

- Presence of protective equipment and accessories are not in sufficient amount.

- Most of the hospitals do not follow proper waste treatment and disposal facilities.

- Most of the hospital have no autoclaves.

- Awareness among the hospital's staff and laborer is not up to the mark.

\section{RECOMMENDATION}

The following recommendations are presented as immediate actions to improve the current situation and require only a commitment to hospital waste management by the staff and its management.

\section{A. Recommended color coding for hospital wastes}

Use of proper containers with specific color codes in all wards can prevent mixing of the different waste types. The volume of infectious waste can be significantly reduced by the segregation of infectious and non-infectious wastes in hospitals in a feasible way. If the wastes are not segregated properly, then the overall waste has to be considered as infectious waste, which in turn increases the health and environmental problems and requires more attention for handling and final disposal.

Table-5. Color Coding of wastes

\begin{tabular}{|c|c|c|}
\hline Type of waste & Color & $\begin{array}{c}\text { Type of } \\
\text { Container }\end{array}$ \\
\hline Clinical & Yellow & $\begin{array}{c}\text { Strong, leak proof } \\
\text { plastic bag }\end{array}$ \\
\hline Sharps & Red & $\begin{array}{c}\text { Puncture proof } \\
\text { container }\end{array}$ \\
\hline Reusable & Black & $\begin{array}{c}\text { leak proof plastic } \\
\text { bag }\end{array}$ \\
\hline General & Green & $\begin{array}{c}\text { Plastic bag or } \\
\text { container }\end{array}$ \\
\hline
\end{tabular}

\section{B. Treatment technology for infectious wastes}

Autoclaving can be used for the treatment of infectious wastes in different wards. It is useful to reduce pollution.

\section{Formulation and implementation of laws, regulation and guidelines}

There is a need of a potential waste management policy and national hospital waste disposal guidelines for Bangladesh. Awareness regarding waste handling among the staff and public is necessary. Recently, global consciousness has developed of the need to enforce stricter controls on the handling and disposal of wastes created by health care facilities.

Government hospitals should act as the leader's models in demonstrating safe disposal of hospital waste.

- Establishment of better communication and sharing information about the risks from hospital waste among all shareholders is very important.

- Public awareness is important to quicken government approach for appropriate treatment.

- Medical treatment trends beyond the national boundary should be considered.

- Economic analysis should be done.

- Modern technology should be implemented.

Incineration is the best way for handling the hospital waste. A central incineration unit can be established in Sylhet for handling the hospital waste of North-eastern zone of Bangladesh. Zonal wise incineration can be worked well in handling hospital waste.

\section{CONCLUSION}

Medical waste management is a basic public health and environmental issue. Particularly in developing countries, the management of waste, especially hospital waste, poses a major problem. Medical establishments for example, hospitals and research institutes create sizable amounts of hazardous waste. By proper management of healthcare wastes, risks both inside and outside healthcare institutions can easily be minimized. Healthcare institutions must ensure the safety of their laborers, provide secure strategies for healthcare waste collection and transportation, and provide necessary installations for safe treatment and disposal of wastes. Once the healthcare waste management plan is prepared, a customary program of examination and survey can be undertaken within the healthcare institution. A good review program could also expose problems and new issues in managing healthcare wastes. By utilizing the survey result of this study and implementing the recommendations in the hospitals as soon as possible can made a big difference in the hospital waste management field of Sylhet city. 


\section{International Journal of Engineering Applied Sciences and Technology, 2019 \\ Vol. 4, Issue 5, ISSN No. 2455-2143, Pages 36-40 \\ Published Online September 2019 in IJEAST (http://www.ijeast.com)}

\section{REFERENCE}

[1] Alagöz, A. Z., and Kocasoy, G. (2008). Improvement and modification of the routing system for the health-care waste collection and transportation in Istanbul, Waste Management, 28(8), (pp.1461-1471).

[2] Abduli, M. A. (1995). Solid waste management in Tehran. Waste Management \& Research, 13(5), (pp.519531). https://doi.org/10.1016/S0734-242X(05)80032-1

[3] Abdulla, F., Qdais, H.A, and Rabi, A. (2008). Site investigation on medical waste management practices in northern Jordan, Waste Management, 28(2), (pp.450458). https://doi.org/10.1016/j.wasman.2007.02.035

[4] Airan, D. S., McMurray, D. T., Airan, L. D., and Bell, J. H. (1980). Hospital Solid Waste Management: A Case Study, Journal of the Environmental Engineering Division, 106(4), (pp.741-755).

[5] Da Silva, C. E., Hoppe, A. E., Ravanello, M. M., and Mello, N. (2005). Medical wastes management in the south of Brazil, Waste Management, 25(6), (pp.600-605). https://doi.org/10.1016/j.wasman.2004.03.002

[6] Li, C.S. and Jenq, F.T. (1993). Physical and Chemical Composition of Hospital Waste, Infection Control \& Hospital Epidemiology, 14(3), (pp.145-150). https://doi.org/10.2307/30148478

[7] Mato, R. and Kassenga, G. R. (1997). A study on problems of management of medical solid wastes in Dar es Salaam and their remedial measures, Resources, Conservation and Recycling, 21(1), (pp.1-16).

[8] Nemathaga, F., Maringa, S., and Chimuka, L. (2008). Hospital solid waste management practices in Limpopo Province, South Africa: A case study of two hospitals, Waste Management, 28(7), (pp.1236-1245).

[9] Prüss-Üstün, A., Giroult, E., Rushbrook, P., and Organization, W. H. (1999a). Safe management of wastes from health-care activities. World Health Organization.

[10] Rushbrook, P. (2000). Starting health care waste management in medical institutions. In OMS health care waste practical information series (Vol. 1). OMS.

[11] Sadeghi, A. (2001). Assessment of collection and disposal management of hospital waste in Mashhad city, MS Thesis of Environmental Health Engineering of Tehran University of Medical Sciences.

[12] Saurabh, G., and Ram, B. (2006). Report: Biomedical waste management practices at Balrampur hospital, Lucknow. India Waste Management \& Research, 24, (pp.584-591).

[13] Tudor, T. L., Noonan, C. L., and Jenkin, L. E. T. (2005). Healthcare waste management: A case study from the National Health Service in Cornwall, United Kingdom, Waste Management, 25(6), (pp.606-615). https://doi.org/10.1016/j.wasman.2004.10.004
[14] Kuchibanda, K. and Mayo, A. W. (2015). Public health risks from mismanagement of health care wastes in Shinyanga Municipality Health facilities, Tanzanini, Scientific World J.

[15] Hossain, M., M. (2014). Assessment of medical waste management system in Khulna city, Bangladesh, M.Sc. thesis, Stanford University. 